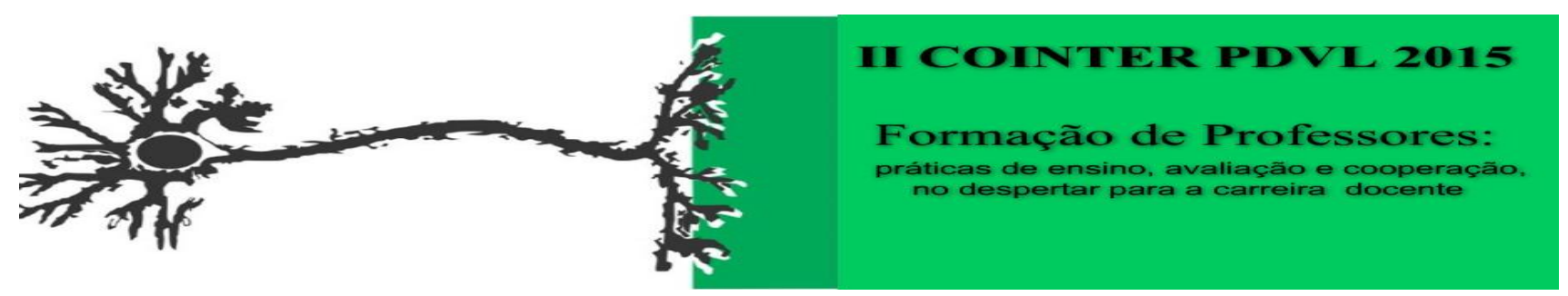

\title{
O ESTÁGIO SUPERVISIONADO NO CURSO DE PEDAGOGIA: UM ESPAÇO DE DECISÃO PARA PROFISSÃO DOCENTE
}

\author{
Apresentação: Relato de Experiência \\ Mádson Francisco da Silva ${ }^{1}$; Natália Maria da Silva ${ }^{2}$ :Paulo Sérgio Dantas da Silva ${ }^{3}$; Ana \\ Maria Sotero Pereira ${ }^{4}$
}

\section{Introdução}

O presente texto, narra um relato de experiência de um licenciando no espaço do estágio supervisionado II, no curso de Pedagogia. Desse modo, no transcorrer do resumo irá se perceber as contribuições do estágio na formação de professores e como ele interferiu na decisão do graduando em querer ser professor, abordando toda fase de experiência dês da chegada do mesmo no campo de estágio, a vivência das atividades e o sentimento que ele teve ao entrar e sair da escola.

\section{Relato de Experiência}

Durante o período de formação docente, especialmente nesse caso, de pedagogia, realiza-se o estágio supervisionado. Nesse viés, é necessário entender que está cadeira é de suma importância para a formação de professores, porque é ela que redimensiona as teorias universitárias, os licenciandos e a escola para estarem em um único campo, em pleno envolvimento. Por outro lado, Pimenta (2001) também compreende o estágio como um espaço de "atividades que os alunos deverão realizar durante o seu curso de formação, junto ao campo futuro de trabalho". Ou seja, essa cadeira é uma oportunidade real da experiência docente que no futuro irá se concretizar. Nesse horizonte, o estágio proporciona oportunidades diretas com a sala de aula e com o cotidiano escolar, onde o estagiário realiza atividades na escola norteado pelo professor(a) universitário(a) e pelo(a) professor(a) regente da unidade de ensino. Sendo assim, no estágio II o estagiário desse relato foi orientado a realizar suas ações educativas em alguma sala do ensino fundamental I, a qual escolheu o quarto ano do turno da manhã. A partir desse momento, o estudante de pedagogia que já estava em seu sexto período e já tinha experiência em monitoria, projetos de extensão e em outros segmentos acadêmicos, se encontrava inseguro e com medo por não saber quais atividades fazer com alunos do ensino fundamental que já tinham entre oito e onze anos. No entanto, depois de pensar e repensar a sua futura prática e até mesmo sua escolha pela carreira docente, o estagiário conseguiu elaborar um plano de aula utilizando o livro de língua portuguesa como auxilio,

\footnotetext{
${ }^{1}$ Pedagogia, Universidade de Pernambuco, mamadson123@hotmail.com

${ }^{2}$ Pedagogia, Universidade de Pernambuco, silva.n.mda@gmail.com

${ }^{3}$ Geografia, Universidade de Pernambuco, paulo_dantas@outlook.com

${ }^{4}$ Mestre em educação, Universidade de Pernambuco, asotero.upe@hotmail.com
} 
intitulando a atividade como "meu pequeno diário", que consistiu na leitura de um gênero textual que se referia ao diário, fomentando nos discentes da escola o prazer pela leitura e escrita partindo de suas próprias experiências de vida, as quais quisessem relatar e depois livremente socializar com a turma. Nessa perspectiva, o estagiário tinha alguns outros objetivos, a saber; perceber a capacidade critica dos alunos e analisar o processo de aprendizagem. No entanto, os primeiros minutos para o estagiário era de desconforto, pois, apesar de estar seguro no que tinha planejado, tinha medo de não alcançar seus objetivos e ter um fracasso na sua práxis. Porém, com o passar dos minutos estava à frente da sala um licenciando seguro e realizado no que estava fazendo, tendo domínio sobre a turma, fortalecendo a relação docente e discente, contribuindo para o desenvolvimento da leitura e da escrita, oportunizando uma nova dinâmica de ensino que nasce do conhecimento já existente e, sobretudo, decidido a ser professor. Porque atuar na sala de aula como docente já não era mais estranho e não lhe proporcionava mais insegurança e medo para a profissão. A escola passou a ser, portanto, um espaço de possibilidades e recomeço.

Imagem 1: Aula no estágio. Fonte: Própria

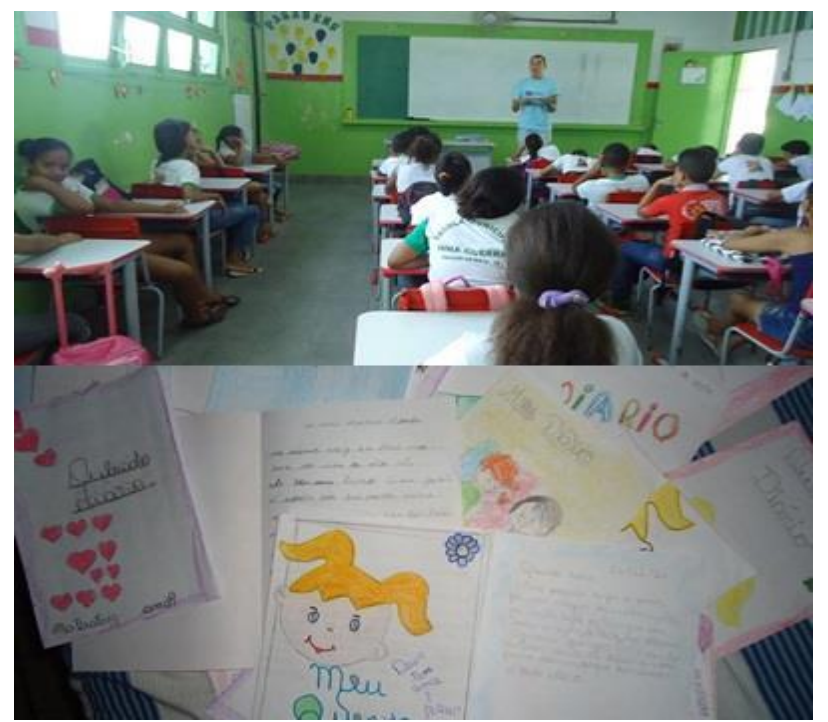

\section{Considerações}

Diante do relato apresentado compreende-se o estágio supervisionado como essencial na formação de professores. Uma vez, que é nesse período que ocorrerá a identificação ou o distanciamento do graduando com a profissão. Nesse viés, depois de considerar está cadeira como chave a docência, vale ressaltar que a universidade tem um papel nesse contexto e precisa atuar fortemente em seus cursos com investimento

teóricos, mas, principalmente com propostas de ações que aproximem formação a profissão docente. Pois, fazendo uma junção do que pensa Tardf e Jardim, é necessário que os professores tenham saberes, porque, são eles os especialistas do campo educativo.

\section{Referências}

JARDIM, A. P. Relação entre Família e Escola: Proposta de ação no processo ensino aprendizagem. Presidente Prudente: Unoeste, 2006.

TARDF, Maurice. Saberes docentes e formação profissional / Maurice Tardif. 14. Ed. Petrópolis, RJ : Vozes, 2012.

PIMENTA, Selma Garrido. O estágio supervisionado na formação de professores: unidade teoria e prática? Selma Garrido Pimenta. -4. Ed. - São Paulo: Cortez, 2001. 